\title{
Successful management of severe gastrointestinal bleeding from jejunal angiodysplasia in a patient with Bernard-Soulier syndrome
}

\author{
Pradip Vekaria, ${ }^{1}$ Kuppusamy Senthamizhselvan (D) ,' Senthil Gnanasekaran, ${ }^{2}$ \\ Pazhanivel Mohan'
}

${ }^{1}$ Medical Gastroenterology, JIPMER, Puducherry, India ${ }^{2}$ Surgical Gastroenterology, JIPMER, Puducherry, India

Correspondence to Dr Kuppusamy

Senthamizhselvan; senthamizh2909@gmail.com

Accepted 25 January 2021

\section{DESCRIPTION}

A 57-year-old woman presented to the emergency department with melena, easy fatiguability and dizziness for 2 days. She did not have haematemesis, abdominal pain, ascites or jaundice. Her routine master health check-up done 4 years previously revealed a diagnosis of Bernard-Soulier syndrome (BSS). She did not have any bleeding manifestation so far. Her personal history and family history were not contributory. On examination, she was drowsy, pale, tachycardic and hypotensive. Her abdomen examination was unremarkable, and digital rectal examination revealed melenic stool staining. Her blood investigations showed severe anaemia (haemoglobin: $54 \mathrm{~g} / \mathrm{L}$ ) and thrombocytopenia (platelet count: $65 \times 10^{9} / \mathrm{L}$ ), with giant platelets on a peripheral smear. She received two units of packed red blood cells. Her initial upper endoscopy, colonoscopy and CT abdominal angiogram did not reveal any abnormality. Video capsule endoscopy showed multiple brisk bleeding spots in the proximal jejunum (figure 1A-D). She received octreotide infusion initially. However, there was no response for over 72 hours, and her haemoglobin value did not improve. Hence, we decided to proceed with diagnostic laparoscopy and intraoperative

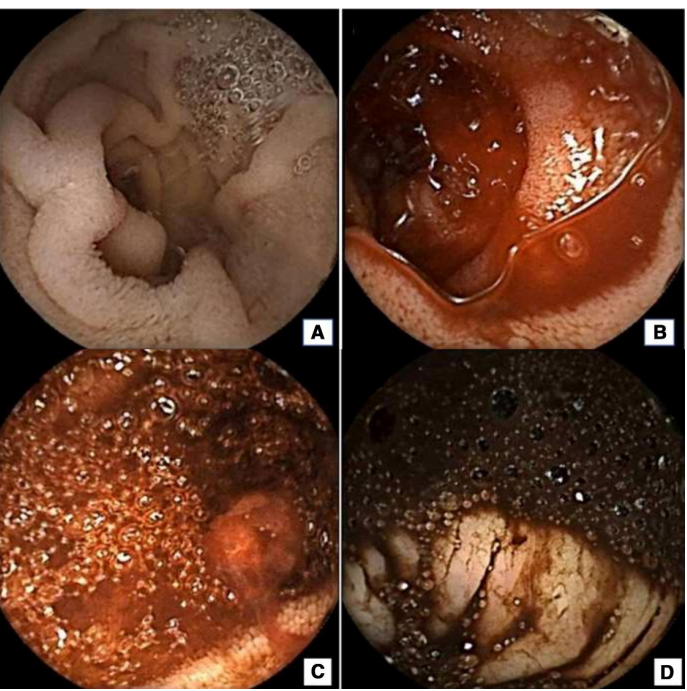

Figure 1 Video capsule endoscopy images showing (A) normal duodenal mucosa, (B) proximal jejunum showing active ooze of blood, (C) distal jejunum showing altered blood and (D) terminal ileum showing black-coloured stool staining of the mucosa.
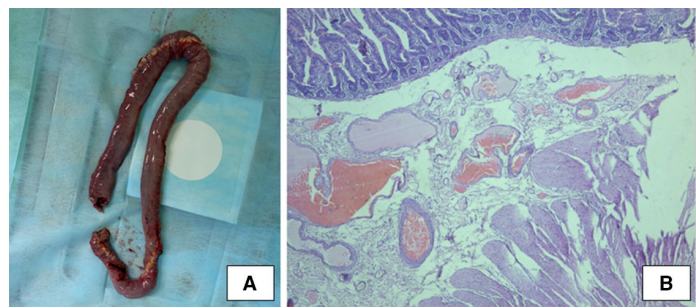

Figure 2 (A) Photograph of the resected segment of the proximal jejunum. (B) Photomicrograph showing the biopsy of the resected segment with normal mucosa, thickened walls of the submucosal blood vessels, veins exhibiting arterialisation of walls and thin-walled capillaries (H\&E: 10x).

enteroscopy. It revealed multiple ectatic cherry red spots in proximal jejunum, with active diffuse pinpoint ooze. She underwent resection of $50 \mathrm{~cm}$ of proximal jejunum in the same sitting (figure 2A). Histopathological examination of the resected bowel confirmed diagnosis of angiodysplasia (AD) (figure 2B). She had an uneventful postoperative period and got discharged in a stable condition. She did not have further bleeding episodes and is doing well for the past 2 years.

$\mathrm{AD}$ is the most frequently reported cause for bleeding from the small bowel. ${ }^{1}$ It presents as chronic anaemia due to occult gastrointestinal (GI) blood loss or an overt GI bleed like melena or haematochezia. The presence of a concomitant systemic condition like chronic kidney disease, aortic stenosis or haemostatic disorder increases the risk of bleeding from ADs. ${ }^{2}$ BSS presenting with GI bleeding from $\mathrm{ADs}$ is rarely encountered. ${ }^{34}$ The association between BSS and AD is not well established, and whether such ADs are more prevalent in BSS or incidentally diagnosed because of bleeding is not known. Video capsule endoscopy is the first-line modality for small bowel evaluation and has a higher diagnostic yield if performed early. Other modalities include CT angiography, push enteroscopy and device-assisted enteroscopy. Intraoperative enteroscopy should be reserved as a final option when other diagnostic modalities fail or are not available. The various treatment modalities for intestinal $A D$ include pharmacological treatment, endoscopy, radiological intervention and surgery. Somatostatin analogues and thalidomide have shown promising results in some patients. ${ }^{5}$ Endoscopic treatment includes argon plasma coagulation, sclerotherapy 
with polidocanol and clipping. In patients with haemodynamic instability, selective angiography and embolisation or coiling may achieve haemostasis. ${ }^{6}$ Due to advancements in endoscopic and radiological techniques, such lesions rarely mandate a surgical treatment nowadays. However, surgery plays an important role when the source of the GI bleeding is not detectable and when there is haemodynamic instability. The prognosis after surgery is generally good, and they have to undergo haemogram during periodic follow-up.

\section{Patient's perspective}

I thank the team of doctors who tried all their best to save me. But I am worried that the bleeding may recur in the future.

\section{Learning points}

- Gastrointestinal angiodysplasias may cause life-threatening bleeding, when associated with a concomitant haemostatic disorder.

- Intraoperative enteroscopy may be helpful when all other options fail.

Recurrence of bleeding must be anticipated for the rest of their life.
Contributors Identification of the case: PV and KS; conception and design: KS; literature search: PV and KS; drafting of the manuscript: PV and KS; critical review of the manuscript: SG and PM; and final approval of the manuscript: KS, SG and PM.

Funding The authors have not declared a specific grant for this research from any funding agency in the public, commercial or not-for-profit sectors.

Competing interests None declared.

Patient consent for publication Obtained.

Provenance and peer review Not commissioned; externally peer reviewed.

ORCID iD

Kuppusamy Senthamizhselvan http://orcid.org/0000-0002-7543-4052

\section{REFERENCES}

1 Sakai $E$, Endo $H$, Taniguchi L, et al. Factors predicting the presence of small bowel lesions in patients with obscure gastrointestinal bleeding. Dig Endosc 2013;25:412-20.

2 Igawa A, Oka S, Tanaka S, et al. Major predictors and management of small-bowe angioectasia. BMC Gastroenterol 2015;15:108.

3 Yüksel 0 , Köklü S, Uçar E, et al. Severe recurrent gastrointestinal bleeding due to angiodysplasia in a Bernard-Soulier patient: an onerous medical concomitance. Dig Dis Sci 2004; 49:885-7.

4 Ouakaa-Kchaou A, Gargouri D, Elloumi H, et al. Intractable gastrointestinal bleeding from angiodysplasia in a patient with Bernard-Soulier syndrome. Ann Hematol 2011;90:861-2.

5 Ge Z-Z, Chen H-M, Gao Y-J, et al. Efficacy of thalidomide for refractory gastrointestinal bleeding from vascular malformation. Gastroenterology 2011;141:1629-37.

6 Sakai E, Ohata K, Nakajima A, et al. Diagnosis and therapeutic strategies for small bowel vascular lesions. World J Gastroenterol 2019;25:2720-33.

Copyright 2021 BMJ Publishing Group. All rights reserved. For permission to reuse any of this content visit https://www.bmj.com/company/products-services/rights-and-licensing/permissions/

BMJ Case Report Fellows may re-use this article for personal use and teaching without any further permission.

Become a Fellow of BMJ Case Reports today and you can:

- Submit as many cases as you like

- Enjoy fast sympathetic peer review and rapid publication of accepted articles

- Access all the published articles

Re-use any of the published material for personal use and teaching without further permission

\section{Customer Service}

If you have any further queries about your subscription, please contact our customer services team on +44 (0) 2071111105 or via email at support@bmj.com.

Visit casereports.bmj.com for more articles like this and to become a Fellow 